\title{
EVALUATION OF THE EFFECT OF VARIOUS NITROGEN FORMS ON THE LUPINUS ALBUS SEED PROTEIN COMPOSITION
}

\author{
Danuta Ciesiolka ${ }^{1}$, TAdeusz Aniszewski ${ }^{2}$, Wojciech Wysocki ${ }^{1}$, \\ RAdOSŁAW PILARSKI ${ }^{1}$, KRZYSZTOF GULEWICZ ${ }^{1 *}$ \\ $1^{*}$ Laboratory of Phytochemistry, Institute of Bioorganic Chemistry PAS \\ Noskowskiego 12/14, 61-704 Poznań, Poland \\ e-mail: krysgul@ibch.poznan.pl \\ ${ }^{2}$ Laboratory of Applied Botany, Department of Biology, University of Joensuu \\ PO Box 111, 80101 Joensuu, Finland
}

(Received: February 23, 2007. Accepted: November 20, 2007)

\begin{abstract}
The influence of different nitrogen forms: $\left(\mathrm{N}_{2}\right),\left[\mathrm{N}_{2}+\left(\mathrm{NH}_{4}{ }^{+}+\mathrm{NO}_{3}^{-}\right)\right],\left(\mathrm{NH}_{4}^{+}\right),\left(\mathrm{NO}_{3}^{-}\right),\left(\mathrm{NH}_{4}{ }^{+}+\mathrm{NO}_{3}^{-}\right)$and $\left(-\mathrm{NH}_{2}\right)$ on changes of albumin, globulin, prolamin-glutelin, non-fractioned nitrogen and non-protein nitrogen fractions of the protein seed of alkaloid-low content Lupinus albus L. cv. Butan has been studied. The experiments were performed in a greenhouse on perlite using in all cases the constant $\mathrm{P}, \mathrm{K}, \mathrm{Mg}$ and micronutrients $(\mathrm{B}, \mathrm{Zn}, \mathrm{Mn}, \mathrm{Cu}$, $\mathrm{Mo}, \mathrm{Fe}$ ) fertilization. The control was the treatment without any nitrogen support (Nd). It was clearly shown that nitrogen form has significant effect not only on the seed yield and seed protein content, but also on the composition of protein fractions and on the biological value of lupin protein. The main protein fraction of the seeds from all treatments were albumins (16.73-26.10 mg N/g). Among all the treatments, the highest level of globulin was observed for the seeds of plant growing with the symbiotic nitrogen form $(15.26 \mathrm{mgN} / \mathrm{g})$, while the lowest one for the control $(\mathrm{Nd})(6.86 \mathrm{mg} \mathrm{N} / \mathrm{g})$. Symbiotic nitrogen $\left(\mathrm{N}_{2}\right)$ treatment clearly increased the glutelin-prolamin fraction while the addition of mineral nitrogen $\left(\mathrm{NH}_{4}{ }^{+}+\mathrm{NO}_{3}{ }^{-}\right)$decreased this fraction from 8.40 to $4.48 \mathrm{mg} \mathrm{N} / \mathrm{g}$. The lowest level of the glutelin-prolamin fraction was in the absence of any nitrogen (Nd). Non-protein fraction (Nnp) was highest in the case of plants treated with $\left(-\mathrm{NH}_{2}\right)(9.92 \mathrm{mgN} / \mathrm{g})$, and the lowest in the absence of nitrogen $(\mathrm{Nd})$ $(4.90 \mathrm{mgN} / \mathrm{g})$. The level of non-fractioned nitrogen $(\mathrm{Nr})$, with exception of $\left[\mathrm{N}_{2}+\left(\mathrm{NH}_{4}{ }^{+}+\mathrm{NO}_{3}^{-}\right)\right]$and $-\mathrm{NH}_{2}$ treatments, was closest to the start material. The protein fractions (albumins, globulins and glutelins and prolamins) were also electrophoretically characterized. These analysis confirmed the changes in protein composition of particular fractions under the effect of various nitrogen forms used as a fertilizer.
\end{abstract}

KEY WORDS: lupin, nitrogen forms, protein, fractional composition.

\section{INTRODUCTION}

Nitrogen that consists of an indispensable element of protein, nucleic acid and other important nitrogen compounds can be uptaken by plants in the form of $\mathrm{NH}_{4}^{+}$or $\mathrm{NO}_{3}^{-}$ and, in specific conditions, in the amide form $-\mathrm{NH}_{2}$ (urea). The preference of plants to the particular form depends mainly on its availability that is conditioned by microbiologic activity dependent on $\mathrm{pH}$, oxygen condition, soil nutrient availability and temperature. Acidofilic and low oxidation-reduction potential tolerating plants uptake easier $\mathrm{NH}_{4}{ }^{+}$cation while the calciphilous ones prefer anion form, $\mathrm{NO}_{3}{ }^{-}$. The increase of soil $\mathrm{pH}$ increases $\mathrm{NH}_{4}^{+}$and decreases $\mathrm{NO}_{3}^{-}$relative uptake rates. At $\mathrm{pH}$ above 7.5, $\mathrm{NH}_{4}^{+}$ undergoes to free $\mathrm{NH}_{3}$. This compound is also formed during reduction of $\mathrm{N}_{2}$ in root nodules of legumes and during hydrolysis of urea used as nitrogen fertilizer. Contrary to
$\mathrm{NO}_{3}^{-}$, ammonia at high concentration is toxic for plants and has to be immediately deactivated by carbon chains. The main source of nitrogen for legumes is atmospheric, gaseous $\mathrm{N}_{2}$. Although currently we are not able to explain all aspects and experimental results concerning the regulation of nitrogen fixation in legumes (Schulze 2004), it is known that nitrogen content in bacterial lupin nodules has an influence on nitrogen content in seeds. Fixation of nitrogen in biological way is not energetically free. Plants have to contribute significant amount of energy in the form of photosynthates (photosynthesis derived sugars) and other nutritional factors for the bacteria. The symbiotic nitrogen fixation by legumes may be inhibited by the presence in soil of both, nitrate and ammonium (Latimore et al. 1977; Evans 1982; Evans et al. 1987; Malik et al. 1987; Carroll and Mathews 1990; Daimon et al. 1999; Daimon and Yoshioka 2000). As shown by Ciesiołka et al. 2005, different 
nitrogen forms used as fertilizer had a significant effect not only on the development and yield of both alkaloid-low and alkaloid-rich lupin cultivars, but also on total raw protein, alkaloid and $\alpha$-galactoside content in seeds. Proteins can be classified into two groups: globular and fibrous proteins (Wilson and Walker 2001). Globular proteins are generally water soluble and they may contain a mixture of $\alpha$-helix, $\beta$-pleated sheet and random structure. Fibrous proteins are structural proteins, generally insoluble in water and consisting of long cable-like structures build entirely of either helical or sheet arrangements. The native state of a protein is its biologically active form. Lupin seed proteins are composed dominantly by globular proteins, but protein quality depends on lupin species and biotype (Aniszewski 1993a, 1993b).

The objective of our studies was alkaloid-low (sweet) lupin L. albus L. cv. Butan. The choice of lupin was not accidental. Lupin could be used as a source of protein or fiber or for supplementation in already existing or new products (Aniszewski 1993a, 1993b; Mohamed and Rayas-Duarte 1995). The feature which distinguishes lupin from among other plants may be determined as follows: $i$. belongs to highest protein plants, $i i$. has modest soil and climatic demands, iii. leaves big organic mass in soil, $i v$. improves airwater conditions of soil, $v$. makes accessible macro and micro elements eluted to sublayer of soil, vi. lupin protein has good functional properties, i.e. emulsifying power, binding, and foaming properties (Edvin 1974; Gulewicz et al. 1994; Aniszewski 1995a, 1995b; Ciesiołka et al. 2005).

The main aim of our studies was to answer the following questions: How do different nitrogen forms affect the quality of seed proteins? Can various nitrogen sources modify the chemical composition of legume proteins and improve or worsen its biological value? The presented studies were supported by the chemical analysis devised by Osborne (1924), which were based on differential solubility of the seed protein fractions (Nelson 1969; Oomah and Bushuk 1983).

\section{MATERIAL AND METHODS}

\section{Greenhouse experiments}

The experiments were carried out on Perlite in a greenhouse at determined conditions within a period of AprilAugust, 2005. The seeds of lupin, sterilized with 1.5\% sodium hypochlorite, were sowed in 1.51 capacity pots, 13 $\mathrm{cm}$ (diameter) $\times 13 \mathrm{~cm}$ (height) filled with Perlite on April 12. Seven fertilizer treatments with different forms of nitrogen were used in the experiment as follows:

$\mathrm{T} 1$ - nitrogen deficiency: $(\mathrm{Nd})$

$\mathrm{T} 2-\mathrm{N}_{2}-$ (Bradyrhizobium lupini $):\left(\mathrm{N}_{2}\right)$

$\mathrm{T} 3-\mathrm{N}_{2}-($ Bradyrhizobium lupini $)+\mathrm{NH}_{4} \mathrm{NO}_{3}$ :

$\left[\mathrm{N}_{2}+\left(\mathrm{NH}_{4}{ }^{+}+\mathrm{NO}_{3}^{-}\right)\right]$

$\mathrm{T} 4-\mathrm{NaNO}_{3}:\left(\mathrm{NO}_{3}^{-}\right)$

$\mathrm{T} 5-\left(\mathrm{NH}_{4}\right)_{2} \mathrm{SO}_{4}:\left(\mathrm{NH}_{4}^{+}\right)$

$\mathrm{T} 6-\mathrm{NH}_{4} \mathrm{NO}_{3}:\left(\mathrm{NH}_{4}{ }^{+}+\mathrm{NO}_{3}{ }^{-}\right)$

$\mathrm{T} 7-\mathrm{NH}_{2} \mathrm{CONH}_{2}:\left(-\mathrm{NH}_{2}\right)$

Each treatment was done in six repetitions. One pot containing three plants constituted one repetition. During vegetation period for each pot of T4, T5, T6, T7 treatments, the total dose $116 \mathrm{mg} \mathrm{N}$ of suitable form was used. The dose was four applications of $29 \mathrm{mg} \mathrm{N}$ one per week. The first nitrogen fertilization was used during the formation of flower buds. In the case of T3 treatment, single dose of $29 \mathrm{mg}$ $\mathrm{N}$ per pot in the form $\left(\mathrm{NH}_{4}{ }^{+}+\mathrm{NO}_{3}{ }^{-}\right)$was applied. $\mathrm{P}_{2} \mathrm{O}_{5}$, $\mathrm{K}_{2} \mathrm{O}, \mathrm{MgO}$ and micronutrients ( $\mathrm{Zn}, \mathrm{Mn}, \mathrm{Cu}, \mathrm{Mo}, \mathrm{Fe}$ ) were used single in the doses of $22.0 ; 34.0 ; 8.0$ and $9.0 \mathrm{mg}$ per pot, respectively. During the vegetation period, the plants were irrigated with water in sufficient amount to avoid the lixiviation of nitrogen from perlite.

\section{Seed harvest and determination of protein}

The seeds were harvested from each combination and analyzed afterwards. The analysis also involved the seeds sowed (SM - start material). The crude protein in seeds from all the treatments and from the SM was determined by Kjedahl method using a Kjeltec Auto Distillation 2200 apparatus (FOSS TECATOR).

\section{Determination of fractional composition of seed proteins}

In general, the fractionation of seeds protein was supported by the method described by Michael and Blume (1961) with some modification (Peretiatkowicz et al. 1988), showed in Figure 1. The total nitrogen amounts of initial material and fractions marked in Figure 1 by a thickened frame (A - albumins, Nnp - non protein nitrogen, $\mathrm{G}$ - globulins, $\mathrm{Gt}+\mathrm{P}$ glutelins and prolamins, Nr-residual nitrogen) were determined by the Kjedahl method.

\section{Sodium dopdecyl sulphate polyacrylamide gel electrophoresis (SDS-PAGE) of protein fractions}

The precipitated albumin fraction with TCA (Fig. 1) was resolved in TBS buffer $(25 \mathrm{mM} \mathrm{NaCl}$ and $25 \mathrm{mM}$ TRIS/HCl $\mathrm{pH} 7.5)$ and passed through the Amicon filter $(10 \mathrm{kD})$. The content of protein in albumins and other lupin fractions was determined according to the Bradford (1976) method. Next, $20 \mu \mathrm{g}$ of protein were precipitated with four volume of acetone. The samples were frozen for $40 \mathrm{~min}$

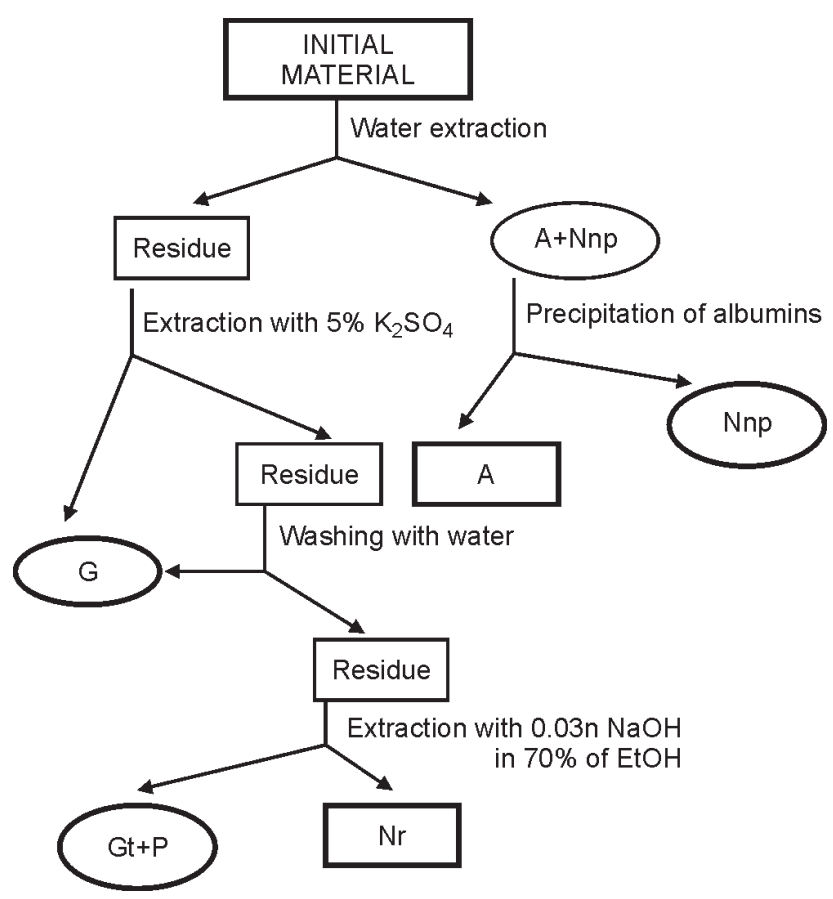

Fig. 1. Scheme of seeds' proteins fractionation.

Nnp - non-protein fraction; A - albumin; G - globulin, Gt+P - glutelin+prolamin; $\mathrm{Nr}$ - residual fraction 
and centrifugated at $12000 \mathrm{rpm}$ for $15 \mathrm{~min}$. After removing of aceton, the pellet was dryed in dessicator. The dry samples were solved in $10 \mu \mathrm{L}$ of water and $10 \mu \mathrm{L}$ of sample buffer (SB) cointaining: $1 \mathrm{~mL}$ glicerol, $0.5 \mathrm{~mL} \beta$-mercaptanol, $2 \mathrm{~mL}$ of $10 \% \mathrm{SDS}, 0.25 \mathrm{~mL}$ of $0.05 \%$ bromophenol blue (BPB) and $1.25 \mathrm{~mL}$ of stocking buffer ( $3 \mathrm{~g}$ of TRIS, $14.4 \mathrm{~g}$ of amino acetic acid and $10 \mathrm{~mL}$ of $10 \%$ SDS-all components in $1000 \mathrm{~mL}$ of water). Afterward, the samples were boiled during $3 \mathrm{~min}$ and applied onto $10 \%$ acrylamide gel. The SDS PAGE was performed on the Biometra Power Pack P25 apparatus at $7.5 \mathrm{~mA}$ (concentrating gel), $14 \mathrm{~mA}$ (developing gel) for 3 hours (Lammeli 1970). Then, the gels were passed to the fixing agent (10\% acetic acid in $50 \%$ ethanol) and dyed with Coomassie Brillant Blue.

\section{Statistical analysis}

Multi-way analysis of variance (ANOVA) was conducted using MATLAB program, version 6.5 (MathWorks Inc.) available at Poznań Supercomputing and Networking Center of the Institute of Bioorganic Chemistry, PAS, Poznań, Poland.

\section{RESULTS}

\section{Yield of seeds, seed protein content and yield of protein}

The yield of seeds, content of protein and yield of protein in seeds harvested from the plants, growing under various nitrogen forms are presented in Table 1. The highest yield of seeds $(38.08 \mathrm{~g})$ was collected in the treatment, where nitrogen was used as $\left[\mathrm{N}_{2}+\left(\mathrm{NH}_{4}{ }^{+}+\mathrm{NO}_{3}\right)\right]$ form, while the lowest one $(2.81 \mathrm{~g})$ in the case of nitrogen deficiency (Nd). Generally, the fixation of nitrogen by lupin increased distinctly the seeds yield in comparison to other nitrogen form used. Similarly, in the case of $\mathrm{N}_{2}$ forms, the content of protein in seeds and the mean yield of protein was at the level of $32 \%$. The content of protein in seed of treatments: $-\mathrm{NH}_{2}, \mathrm{Nd}$ and $\mathrm{NH}_{4}{ }^{+}+\mathrm{NO}_{3}$ was on the level of $30 \%$. The seeds collected from the treatments $\mathrm{NH}_{4}{ }^{+}$or $\mathrm{NO}_{3}{ }^{-}$contained lower amount of protein ca. $27 \%$. The yield of protein was also highest for both treatments with symbiotic nitrogen $(11.12$ and $12.30 \mathrm{~g})$. The relatively lowest yield of protein $(0.824 \mathrm{~g})$ for $\mathrm{Nd}$ treatment was observed.

\section{Changes of protein fractions}

The results of fractional composition of starting material (SM) - the seeds used for sowing and the seeds collected from various nitrogen treatments are presented in Table 2. In contrast to SM where main proteins were globulins $(20.16 \mathrm{mg} \mathrm{N} / \mathrm{g})$, the main protein fraction of seeds from all treatments were albumins, from 17.71 to $27.16 \mathrm{mg} \mathrm{N} / \mathrm{g}$ for
$\left(\mathrm{NH}_{4}^{+}\right)$and $\left(\mathrm{NO}_{3}^{-}\right)$treatments, respectively, and the differences between particular treatments were statistically significant, except the $\mathrm{Nd}$ treatment where albumin content was the same as in SM. Among all of the treatments, the highest level of globulin was found for $\mathrm{N}_{2}$ treatment (15.26 $\mathrm{mg} \mathrm{N} / \mathrm{g}$ ), while the lowest one for nitrogen deficiency $(\mathrm{Nd})$ $(6.86 \mathrm{mg} \mathrm{N} / \mathrm{g})$. The closest level of $\mathrm{Gt}+\mathrm{P}$ in relation to $\mathrm{SM}$ shows $\mathrm{N}_{2}$ treatment, although statistically significant difference between them was observed. Addition of mineral nitrogen form to the $\mathrm{N}_{2}$ treatment caused significant decrease of the Gt+P content from 8.40 to $4.48 \mathrm{mg} \mathrm{N} / \mathrm{g}$. The lowest level of these proteins for $\mathrm{Nd}$ was noted. All non-protein fractions (Nnp), with exception of $\left[\mathrm{N}_{2}+\left(\mathrm{NH}_{4}{ }^{+}+\mathrm{NO}_{3}{ }^{-}\right)\right]$treatment, differ statistically from SM and between particular nitrogen forms. The residue fraction $(\mathrm{Nr})$, with exception for $\left[\mathrm{N}_{2}+\left(\mathrm{NH}_{4}{ }^{+}+\mathrm{NO}_{3}{ }^{-}\right)\right]$treatment, was about $2.2 \mathrm{mg} \mathrm{N} / \mathrm{g}$. The lowest statistical difference was observed in these fractions. The comparison of total $\mathrm{mg} \mathrm{N}$ in protein fractions with total $\mathrm{mg} \mathrm{N}$ in seeds shows that the used method is very accurate, which confirms high level of recovery from 97.84 to $102.09 \%$ (Table 2).

Figure 2 presents elecrophorograms of particular protein fractions of lupin seeds collected from different nitrogen treatments where the particular fractions differ among themselves with protein composition. Also, within the framework of fraction, the effect of nitrogen form is clear. In the case of albumin, the decay of protein ca.76.5 kDa, characteristic for SM (line 8), in case of the treatments $\mathrm{N}_{2}$ (line 2), $\mathrm{N}_{2}$ +both mineral nitrogen form (line 3), $\mathrm{NO}_{3}^{-}$(line 4) and $-\mathrm{NH}_{2}$ (line 7 ) is observed. Significant difference occurs between proteins with molecular weight ca. 61.56; $49.0 ; 47.5$ and $25.9 \mathrm{kDa}$. The globulin fraction shows totally different protein composition in relation to albumin fraction. Additionally, in this case the nitrogen form has influence on intensity of some protein bands. It especially concerns the proteins 60.5 and $30.5 \mathrm{kDa}$. For glutelin and prolamin, high non-migrating molecular protein is observed in all cases of nitrogen forms. Some differences in intensity of bands are showed for line 7 , particularly for $60.5 \mathrm{kDa}$ protein. This protein occurs in the highest content in comparison to other nitrogen form. Moreover, some differences between nitrogen forms are visible for proteins with molecular weight of $40 \mathrm{kDa}$.

\section{DISCUSSION}

Storage protein form is an important group of plant proteins which provide nitrogen and amino acids for developing seedlings and constitute a major source for human and livestock consumption. In this regard, main economic im-

TABLE 1. Yield of seeds, content of protein in seeds and yield of protein from proper treatment.

\begin{tabular}{|c|c|c|c|c|c|c|c|}
\hline & \multicolumn{7}{|c|}{ Nitrogen forms/Treatments } \\
\hline & $\mathrm{T} 1 *$ & $\mathrm{~T} 2$ & $\mathrm{~T} 3$ & $\mathrm{~T} 4$ & T5 & T6 & $\mathrm{T} 7$ \\
\hline Yield of seeds from treatment (g) & 2.81 & 34.32 & 38.08 & 15.66 & 6.86 & 11.27 & 8.96 \\
\hline Percentage content of protein in seeds & 29.34 & 32.40 & 32.29 & 27.52 & 27.00 & 29.03 & 30.40 \\
\hline Yield of protein from treatment $(\mathrm{g})$ & 0.82 & 11.12 & 12.30 & 4.30 & 1.85 & 3.27 & 2.72 \\
\hline
\end{tabular}

$* \mathrm{~T} 1-\mathrm{Nd} ; \mathrm{T} 2-\mathrm{N}_{2} ; \mathrm{T} 3-\mathrm{N}_{2}+\mathrm{NH}_{4}{ }^{+}+\mathrm{NO}_{3} ; \mathrm{T} 4-{ }_{-} \mathrm{NO}_{3} ; \mathrm{T} 5-\mathrm{NH}_{4}{ }^{+} ; \mathrm{T} 6-\mathrm{NH}_{4}{ }^{+}+\mathrm{NO}_{3} ; \mathrm{T} 7--\mathrm{NH}_{2}$

The content of protein in the seeds of start material (SM) was $35.55 \%$ 
TABLE 2. Proteins composition of starting material (SM) and the lupin seeds collected from different treatments (mg N/g of seeds).

\begin{tabular}{|c|c|c|c|c|c|c|c|c|}
\hline \multirow{2}{*}{ Nitrogen form } & \multicolumn{5}{|c|}{ Fractions } & \multirow{2}{*}{$\begin{array}{c}\text { Total } \mathrm{N} \\
\text { in protein fr. } \\
(\mathrm{mg} / \mathrm{g} \text { of seeds) }\end{array}$} & \multirow{2}{*}{$\begin{array}{c}\text { Total } \mathrm{N} \text { in seeds } \\
(\mathrm{mg} / \mathrm{g})\end{array}$} & \multirow{2}{*}{$\begin{array}{c}\text { Recovery } \\
(\%)\end{array}$} \\
\hline & Nnp & A & G & $\mathrm{Gt}+\mathrm{P}$ & $\mathrm{Nr}$ & & & \\
\hline SM & $\begin{array}{c}7.21 \pm 0.17 * \\
\mathrm{a}^{* *}\end{array}$ & $\begin{array}{c}18.27 \pm 0.1 \\
\mathrm{a}\end{array}$ & $\begin{array}{c}20.16 \pm 0.4 \\
\mathrm{a}\end{array}$ & $\begin{array}{c}7.84 \pm 0.10 \\
\mathrm{a}\end{array}$ & $\begin{array}{c}2.17 \pm 0.31 \\
\text { ae }\end{array}$ & 55.65 & 56.88 & 97.84 \\
\hline $\mathrm{Nd}$ & $\begin{array}{c}4.90 \pm 0.10 \\
b\end{array}$ & $\begin{array}{c}18.62 \pm 0.5 \\
\mathrm{a}\end{array}$ & $\begin{array}{c}6.86 \pm 0.27 \\
b\end{array}$ & $\begin{array}{c}1.82 \pm 0.21 \\
\mathrm{~b}\end{array}$ & $\begin{array}{c}2.10 \pm 0.30 \\
\mathrm{a}\end{array}$ & 34.30 & 34.86 & 98.39 \\
\hline $\mathrm{N}_{2}$ & $\begin{array}{c}6.76 \pm 0.14 \\
\mathrm{c}\end{array}$ & $\begin{array}{c}19.6 \pm 0.13 \\
b\end{array}$ & $\begin{array}{c}15.26 \pm 0.9 \\
\mathrm{c}\end{array}$ & $\begin{array}{c}8.40 \pm 0.51 \\
\mathrm{c}\end{array}$ & $\begin{array}{c}1.82 \pm 0.01 \\
\mathrm{~b}\end{array}$ & 51.84 & 52.50 & 98.74 \\
\hline $\mathrm{N}_{2}+\mathrm{NH}_{4}^{+}+\mathrm{NO}_{3}^{-}$ & $\begin{array}{c}7.21 \pm 0.05 \\
\mathrm{a}\end{array}$ & $\begin{array}{l}23.1 \pm 0.92 \\
\mathrm{c}\end{array}$ & $\begin{array}{c}12.04 \pm 0.6 \\
\mathrm{~d}\end{array}$ & $\begin{array}{c}4.48 \pm 0.09 \\
\mathrm{~d}\end{array}$ & $\begin{array}{c}4.83 \pm 1.19 \\
\mathrm{c}\end{array}$ & 51.66 & 51.38 & 100.54 \\
\hline $\mathrm{NH}_{4}^{+}$ & $\begin{array}{c}5.67 \pm 0.05 \\
\mathrm{e}\end{array}$ & $\begin{array}{c}17.71 \pm 0.0 \\
\mathrm{e}\end{array}$ & $\begin{array}{c}13.30 \pm 0.42 \\
\mathrm{f}\end{array}$ & $\begin{array}{c}3.71 \pm 0.13 \\
\mathrm{f}\end{array}$ & $\begin{array}{c}2.80 \pm 0.06 \\
\mathrm{~d}\end{array}$ & 43.19 & 42.42 & 101.81 \\
\hline $\mathrm{NH}_{4}^{+}+\mathrm{NO}_{3}^{-}$ & $\begin{array}{c}4.90 \pm 0.21 \\
b\end{array}$ & $\begin{array}{c}16.73 \pm 0.15 \\
\mathrm{f}\end{array}$ & $\begin{array}{c}11.55 \pm 0.24 \\
\mathrm{~d}\end{array}$ & $\begin{array}{c}4.28 \pm 0.53 \\
\mathrm{~d}\end{array}$ & $\begin{array}{l}2.59 \pm 0.40 \\
\text { ed }\end{array}$ & 40.05 & 41.58 & 96.32 \\
\hline$-\mathrm{NH}_{2}$ & $\begin{array}{c}9.92 \pm 0.14 \\
\mathrm{f}\end{array}$ & $\begin{array}{c}26.10 \pm 0.3 \\
\mathrm{~g}\end{array}$ & $\begin{array}{c}14.56 \pm 0.1 \\
\mathrm{c}\end{array}$ & $\begin{array}{c}3.00 \pm 0.37 \\
\mathrm{~g}\end{array}$ & $\begin{array}{c}1.40 \pm 0.34 \\
\mathrm{f}\end{array}$ & 54.96 & 54.10 & 101.59 \\
\hline
\end{tabular}

$*$ standard deviation $(\mathrm{SD}) ; * *$ letters a-g indicate statistical significance at $\mathrm{p}<0.05$

$\mathrm{Nnp}$ - non-protein fraction; A - albumin; G - globulin, $\mathrm{Gt}+\mathrm{P}$ - glutelin+prolamin; $\mathrm{Nr}$ - residual fraction

portance is attributed to plants of the Graminae, particularly Fabaceae family. Till now, the best studied and utilized legume has been soybean. The great success of soybean as a source of protein initiated intensive investigations on other legumes and particularly lupin that, except high protein content, belongs to unique ecological plants (Gulewicz et al. 1994). Our present study concentrates on determination of how various nitrogen forms used as fertilizer affect composition of seed proteins of L. albus. This question may be especially important for the nutritive value of seed proteins. This statement was confirmed by the results presented in Table 1, where clear effect of nitrogen form on the yield of seeds, content of protein and yield of protein in seeds were observed. These results are in agreement with our earlier studies (Ciesiołka et al. 2005) as well. The highest protein content in seeds was found in the treatments where nitrogen in the forms of $\mathrm{N}_{2},\left[\mathrm{~N}_{2}+\left(\mathrm{NH}_{4}{ }^{+}+\mathrm{NO}_{3}{ }^{-}\right)\right]$and $-\mathrm{NH}_{2}$ was used (Table 1). The other nitrogen forms brought much poorer results. It is worth to emphasize that only in the case $\mathrm{N}_{2}$ and $\left[\mathrm{N}_{2}+\left(\mathrm{NH}_{4}{ }^{+}+\mathrm{NO}_{3}{ }^{-}\right)\right]$treatments, high level of seeds protein content corresponds to high yield of seed protein. In other treatments, the seeds protein content did not correlate with the yield of protein. It shows that at determined conditions of the experiment only fixation of atmospheric nitrogen by lupin may create the best conditions for protein accumulation in seeds. According to Blagrove and Gillespie (1975), Duranti and Cerletti (1983), the major proteins of lupin seeds are a group of globulins called conglutins. The globulin fraction contains two major proteins: conglutin $\alpha(11 S)$ and $\beta$ (7S) (acidic) and a lupin-specific proteins called conglutin $\gamma$ (7S) (basic) and conglutin $\delta$ 2S (Blagrove and Gillespie 1975; Restani et al. 1981; Cerletti et al. 1988; Lambert and Yarwood 1992; Petterson 1998 Sepulveda et al. 1999). In correspondence with this finding are the results of start material only (Table 2). However, these seeds used in our experiment originated from field cultivation. When the same lupin seeds were cultivated on perlite in greenhouse conditions, the predominant fraction was albumins. It proves that both soil and environmental conditions may have effect on fractional composition of lupin proteins. However, taking into consideration that experimental conditions for all treatments were the same, we have been able to observe the effect of different nitrogen forms on chemical composition of protein fraction. This statement confirms the fact that in the $\left(\mathrm{N}_{2}\right)$ treatment, the closest to natural condition of nitrogen fixation, a similar difference exists between albumins and globulins in comparison to start material (SM). The statistical difference of protein level within the framework of the same fraction certifies significant effect of nitrogen form on fractional composition. Similarly, the level of storage protein fractions of all nitrogen forms, except $\mathrm{N}_{2}$, is lower in comparison to SM and statistical significant difference between the treatments certifies distinct effect of nitrogen form on the formation of this fraction. It is worth to mention that in the case of the treatment where any nitrogen was used $(\mathrm{Nd})$, the level of $\mathrm{Gt}+\mathrm{P}$ was the lowest. Diversified level of nitrogen in non-protein fractions (Nnp), in particular the treatments, may certify that nitrogen forms affect the incorporation of amino acids to protein structure. As we know, the Nnp fraction is represented mainly by free amino acids and peptides, and total nitrogen of this fraction depends on physiological state of plant and seed. The increased level of this fraction, as in the case of $-\mathrm{NH}_{2}$ form (Table 2), may be a result of not terminated protein synthesis or disintegration of protein for amino acids. Another explanation is that just $-\mathrm{NH}_{2}$ form is influenced by nitrates accumulations as it took place in the case of spinach (Gulser 2005). The 
Albumin

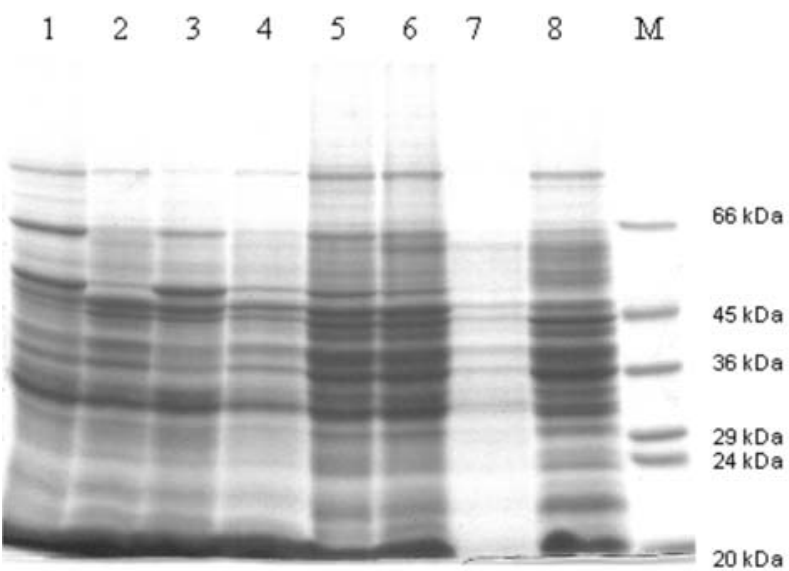

Globulin

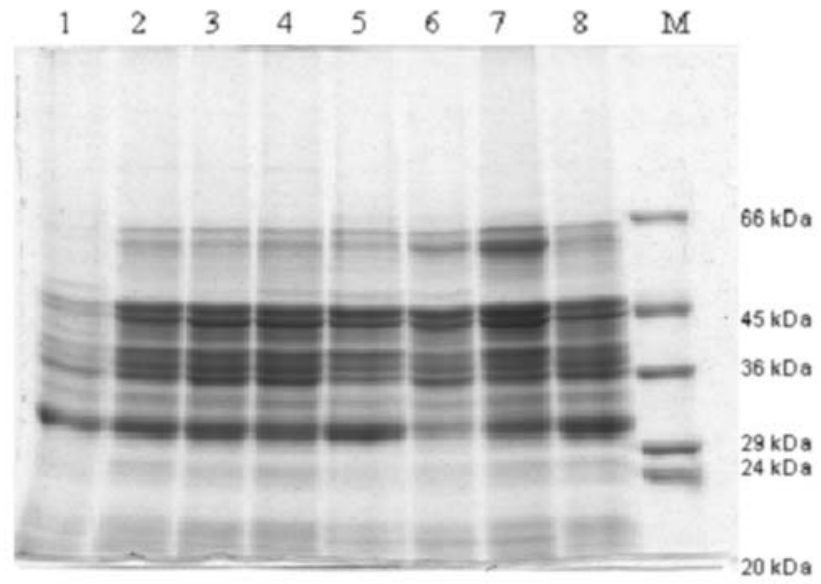

Glutelin \& Prolamin

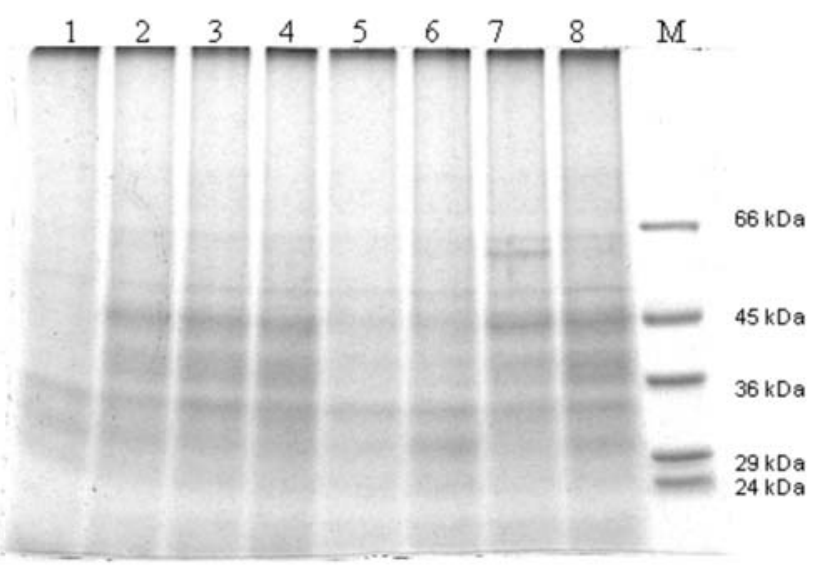

Fig. 2. Sodium dodecyl sulphate polyacrylamide gel electrophoresis (SDS_PEAG).

Lines: $1-\mathrm{Nd} ; 2-\mathrm{N}_{2}, 3-\mathrm{N}_{2}$ tboth ions $\mathrm{NH}_{4}^{+}$and $\mathrm{NO}_{3}^{-} ; 4-\mathrm{NO}_{3}^{-} ; 5-$ $\mathrm{NH}_{4}^{+} ; 6-\mathrm{NH}_{4}^{+}+\mathrm{NO}_{3}^{-} ; 7--\mathrm{NH}_{2} ; 8-\mathrm{SM} ; \mathrm{M}-$ marker

decrease of $\mathrm{Nnp}$, as in case of for example $\mathrm{Nd}, \mathrm{NH}_{4}{ }^{+}$and $\mathrm{NH}_{4}{ }^{+}+\mathrm{NO}_{3}{ }^{-}$forms proves additional incorporation of amino acids of these fractions to protein synthesis. From nutritional point of view, non-protein nitrogen ( $\mathrm{Nnp}$ ) may be of considerable importance (Hill 1977). Non-fractionated nitrogen $(\mathrm{Nr})$ fractions, composed of nucleic acids compounds (purines, pyrimidines), poliamines and non-fractionated protein of wall cells in all treatments, except $\mathrm{N}_{2}$ and
$-\mathrm{NH}_{2}$ forms, are closest to SM. It is worth to note that low level of $(\mathrm{Nr})$ at $\mathrm{N}_{2}$ and $-\mathrm{NH}_{2}$ treatments is connected with increase of level of Nnp fraction. It is especially visible in the $-\mathrm{NH}_{2}$ treatment. The distinct increase of level of $\mathrm{GT}+\mathrm{P}$ fraction in the case of additional dose of nitrogen in the treatment $\left.\left[\mathrm{N}_{2}+\mathrm{NH}_{4}{ }^{+}+\mathrm{NO}_{3}{ }^{-}\right)\right]$may be caused by e.g. increase of polyamine content in the seeds (Aniszewski et al. 2001). It should be also emphasized that biological nitrogen $\left(\mathrm{N}_{2}\right)$ clearly increased $\mathrm{Gt}+\mathrm{P}$ protein fraction, and additional nitrogen $\left.\left[\mathrm{N}_{2}+\mathrm{NH}_{4}{ }^{+}+\mathrm{NO}_{3}^{-}\right)\right]$decreased it.

Elecrophorograms of protein fractions collected from different nitrogen treatments confirming that nitrogen forms have effect not only on quantitative change of protein fractions, but also on the quality one. The results presented in Figure 2 are in agreement with literature data of Blagrove and Gillespie (1975) who showed that conglutin $\alpha$ had been found to release three or four types of subunits with an apparent MW in the range 55 000-800 $000 \mathrm{Da}$, each of which may contain a disulphide-bonded moiety with a MW near $20000 \mathrm{Da}$ and conglutin $\beta$ yielded four subunits in the range $20000-80000$ Da with no covalent links. Conglutin $\gamma$ contains one subunit of MW 40000 composed of two disulphide-linked peptides of MW 17000 and 30000 Da.

In the light of presented results, it is worth to give emphasis to the used protein fractionation method. There are two-way determination of nutritive value of seeds protein: first one is direct, based on nutritional experiment, and the second one is indirect, based on chemical analysis. Although the former gives most reliable results, it is an expensive and labor and time consuming method, and is not suitable for wide use. The chemical method of evaluating nutritive value of proteins is based on determination of general nitrogen that may be counted over on the so-called "crude protein", and determination of its fractional composition. Certainly, we are aware of the possibly existing critical viewpoints connected with the term "crude protein" (Tkachuk 1969; Cherry 1977; Ewart 1981; Boisen et al. 1987; Haque et al. 1989). However, the interpretation of such analysis is based on the assumption that structural protein, e.g. albumins, as a rule has richer amino acid composition and higher biological value than storage protein. So, increase of albumin, Nnp (containing free amino acids, peptide) and decrease of residue fraction $\mathrm{Nr}$, using different nitrogen forms, should be beneficial from nutrition point of view. We observed the case when the treatment $-\mathrm{NH}_{2}$ was used (Table 2). In this case, we observed increase of albunin fraction from 18.27 to $26.10 \mathrm{mg} \mathrm{N} / \mathrm{g}$ and Nnp fraction from 7.21 to $9.92 \mathrm{mg} \mathrm{N} / \mathrm{g}$ and decrease of $\mathrm{Nr}$ fraction from 2.17 to $1.40 \mathrm{mg} \mathrm{N} / \mathrm{g}$. Unfortunately, using nitrogen in $-\mathrm{NH}_{2}$ form (urea), similarly to other mineral forms, affects principal yield of seeds, content of protein in the seeds, and yield protein (Table 1).

\section{ACKNOWLEDGEMENTS}

The seeds of L. albus cv. Butan were kindly supplied by Dr. Stanisław Stawiński of the Plant Breeding and Acclimatization Station at Przebędowo near Poznań, Poland. The cultures of Bradyrhizobium lupini were supplied by the Institute of Soil Science and Plant Cultivation at Puławy, Poland. 


\section{LITERATURE CITED}

ANISZEWSKI T. 1993a. Lupine: a Potential Crop in Finland. Studies on the Ecology, Productivity and Quality of Lupinus spp. PhD Thesis. Faculty of Sciences. University of Joensuu. Joensuu.

ANISZEWSKI T. 1993b. Lupine: a Potential Crop in Finland. Studies on the Ecology, Productivity and Quality of Lupinus spp. PhD Thesis Summary. Faculty of Sciences. University of Joensuu. Publications in Sciences. 29: 1-50.

ANISZEWSKI T. 1995a. Interaction between legume and soil. Sci. Legumes. 2: 172-189.

ANISZEWSKI T. 1995b. Analysis of the lupine-soil system. Sci. Legumes. 2: 190-204.

ANISZEWSKI T., CIESIOŁKA D., GULEWICZ K. 2001. Equilibrium between basic nitrogen compounds in lupin seeds with differentiated alkaloid content. Phytochem. 57: 43-50.

BLAGROVE R.J., GHILLESPIUE J.M. 1975. Isolation, purification and characterization of the seeds globulins of Lupinus angustifolius. Aus. J. Plant Physiol. 2: 13-27.

BRADFORD M. 1976 A rapid and sensitive method for the quantitation of microgram quantities of protein utilizing the principle of protein - dye binding. Anal. Biochem. 72: 248-254.

BOISEN S., BECH-ANDERSEN S., EGGUM B.O. 1987. A Critical View on the Conversion Factor 6.25 from Total Nitrogen to Protein. Acta Agr. Scand. 37: 299-304.

CARROLL B.J., MATHEWS A. 1990 Nitrate inhibition of nodulation in legumes. In: Gresshoff P.M. (ed.), Molecular biology of symbiotic nitrogen fixation. CRC Press Inc., Boca Raton Florida: 159-180.

CERLETTI P., DURANTI M., GUERRIERI N., GIANI D. 1988. Structure and transformations of legumin-like proteins in lupin seeds. Proc. 5th Inter. Lupin Conference, Poznań, July 1988, 277-290.

CHERRY J.P. 1977. Potential sources of peanut seed proteins and oil in the genus Arachis. J. Agr. Chem. 25: 186-193.

CIESIOŁKA D., MUZQUIZ M., BURBANO C., ALTARES P., PEDROSA M.M., WYSOCKI W., FOLKMAN W., POPENDA M., GULEWICZ K. 2005. An effect of various nitrogen forms used as fertilizer on the Lupinus albus L. yield and protein, alkaloids and $\alpha$-galactosides content J. Agr. Crop. Sci. 191: 458-463.

CIESIOŁKA D., GULEWICZ P., MARTINEZ-VILLALUENGA C., PILARSKI R., BEDNARCZYK M., GULEWICZ K. 2005. Products and biopreparations from alkaloid - rich Lupin in animal nutrition and agriculture. Folia Biologica (Kraków) 53: 59-66 (Suppl.)

DAIMON H., HORI K., SHIMIZU A., NAKAGAWA M. 1999. Nitrate induced inhibition of root nodule formation and nitrogenase activity in the peanut (Arachis hypogaea). Plant Prod. Sci. 2: 81-86.

DAIMON H., YOSHIOKA M. 2000. Responses of root nodule formation and nitrogen fixation activity to nitrate in a split-root system in peanut. J. Agr. Crop. Sci. 187: 89-95.

DURANTTI M., CERLETTI P. 1983. Molecular properties and the composition of the globulins from lupin seeds. In: Thompson R., Casey R. (eds), Perspectives for peas and lupins as protein crops. Hague. pp. 227-240.

EWART J.A.D. 1981. Determination of carboxyl groups in wheat and barley flour proteins. J. Sci. Food Agri. 32: 572-578.

EDWIN L.H. 1974. Composition of protein quality of sweet lupin seed. J. Sci. Food Agri. 25: 851-859.

EVANS J. 1982. Response of soybean - Rhizobium symbiosis to mineral nitrogen. Plant Soil. 66: 439-442.
EVANS J., O'CONNOR G.E., TURNER G.L., BERGERSEN F.J. 1987. Influence of mineral nitrogen on nitrogen fixation by lupin (Lupinus angustifolius) as assessed by ${ }^{15} \mathrm{~N}$ isotope dilution methods. Field Crops Res. 17: 109-120.

GULEWICZ K., PERETIATKOWICZ M., BRATEK-WIEWIÓROWSKA M.D., WIEWIÓROWSKI M. 1994. Bitter lupin seeds and straw as raw materials in ecological agriculture. Proceedings of the 7th International Lupin Conference "Advances in Lupin Research", 18-23 April, Evora, Portugal, 312-333.

GULSER R. 2005. Effects of ammonium sulphate and urea on $\mathrm{NO}_{3}{ }^{-}$and $\mathrm{NO}_{2}{ }^{-}$accumulation, nutrients content and yield criteria in spinach. Scientia Horticulturae 106: 330 - 340.

HAQUE A., NJAA L.R., OPSTVEDT J. 1989. Sequence in which amino acids of fish meal protein become limiting for the growing chicken, as determined by "the complete protein evaluation method". Acta Agr. Scand. 39: 301-309.

HILL G.D. 1977. The composition and nutritive value of lupin seeds. Nutrition abstracts and reviews. Series B. 47: 511-528.

LAEMMLE U.K. 1970. Cleavage of structural proteins during. the assembly of the head of bacteriophage T4. Nature. 227: 680-685.

LAMBERT G.G., YARWOOD J.N. 1992. Engineering legume seed storage proteins. In: Plant protein engineering. Cambridge University Press, Cambridge.

LATIMORE M.J.R., GIDDENS J., ASHLEY D.A. 1977. Effect of ammonium and nitrate upon photosynthetic supply and nitrogen fixation by soybeans. Crop Sci. 17: 399-404.

MALIK N.S.A., CALVERT H.E., BAUER W.D. 1987. Nitrate induced regulation of nodule formation in soybean. Plant Physiol. 84: 266-271.

MICHAEL G., BLUME B. 1961. Die Eiweissqualität von Körner verschiedener Getreidearten and Abhängigkeit von Stickstoffversorgung und Entwicklungszustand. Z. Pfl.-Ernähr. Düng. Bodenk. 92: 106-111

MOHAMED A.A., RAYAS-DUARTE P. 1995. Composition of Lupinus albus. Cereal Chem. 72: 643-647.

NELSON O.E. 1969.Genetic modification of protein quality in plants. Adv. Agron. 21: 171-194.

OOMAH B.D., BUSHUK W. 1983. Characterization of lupine proteins. J. Food Sci. 48: 38-41.

OSBORNE T.B. 1924. The Vegetable Proteins. Longmans Green. London.

PERETIATKOWICZ M., WOJTASZEK P., STENCEL M., GULEWICZ K. 1988. The comparison and characterization of the protein composition of lupinus species and other Papilionaceae in Poland. Lupin Newsletter. 11: 33-37.

PETTERSON D.S. 1998. Composition and food uses of lupins. In: Gladstones J.S., Atkins C., Hamblin J. (eds), Lupins crop plants. CAB International.

RESTANI P., DURANTI M., CERLETTI P., SIMONETTI P. 1981. Subunit composition of the seed globulins of Lupinus albus. Phytochemistry. 20: 2077-2083.

SCHULZE J. 2004. How are nitrogen rates regulated in legumes? J. Plant. Nut. Soil Sci. 167, 2: 125-137.

SEPULVEDA J.G., DAVILA O.G., RODRIGUEZ M.M. 1999. Globulins in seeds from Lupinus campestris. Proc. 8th Inter. Lupin Conference Asilomar California, 11-16 May: 214-219.

TKACHUK R. 1969. Nitrogen-to-nitrogen conversion factors for cereals and oilseed meals. Cereal Chem. 46: 419-424.

WILSON K., WALKER J. 2001. Principles and techniques of practical biochemistry. 5th ed., Cambridge University Press. Cambridge. 